\title{
Characteristics and Genesis of the Groundwater Resources Associated with Oil Shale Deposits in the Azraq and Harrana Basins, Jordan
}

\author{
Ali M. Obeidat, Omar Rimawi \\ Department of Geology, Faculty of Science, The University of Jordan, Amman, Jordan \\ Email: Aalobeid2000@yahoo.com, rimawiom@ju.edu.jo
}

How to cite this paper: Obeidat, A.M. and Rimawi, O. (2017) Characteristics and Genesis of the Groundwater Resources Associated with Oil Shale Deposits in the Azraq and Harrana Basins, Jordan. Journal of Water Resource and Protection, 9, 121-138. https://doi.org/10.4236/jwarp.2017.92010

Received: December 4, 2016

Accepted: February 1, 2017

Published: February 4, 2017

Copyright $\odot 2017$ by authors and Scientific Research Publishing Inc. This work is licensed under the Creative Commons Attribution International License (CC BY 4.0).

http://creativecommons.org/licenses/by/4.0/ (c) (i) Open Access

\begin{abstract}
Upper cretaceous and lower tertiary formations groundwater aquifers are associated with huge reserves of oil shale deposits in Harrana and Azraq Basins are evaluated in terms of water qualities and hydrochemical processes. The oil shale deposits are found within the Muwaqqar Chalk Marl Formation. The Muwaqqar Chalk Marl Formation represents the intermediate formation between the Lower Aquifer Amman Silicified Limestone and the overburden, which represents the overlying Upper Aquifers of Um Rijam Chalk and Wadi Shallala Chalk. This study aimed to improve the understanding of Muwaqqar Chalk Marl Formation as a sealing potential based on water quality and hydrochemical data of the different aquifers. Sixty water samples were collected from Amman Silicified Limestone Aquifer, High Grade Zone of Muwaqqar Chalk Marl Formation and from the overburden of Um Rijam Chalk and Wadi Shallala Chalk aquifers. The evaluations of the main hydrochemical processes affecting the groundwater quality were carried out by interpreting the ionic relationships and the water quality types using Piper and Durov diagrams. Comprehensive statistical analyses (Factor and Cluster Analyses) were conducted on the water quality parameters. The factor analyses can extract four factors from the water quality parameters of the Harrana wells Area-1 and for Azraq wells in Area-2. These factors are used to interpret the different geochemical processes affecting the groundwater quality parameters. Cluster analyses divided the Harrana wells into three groups. Cluster I included 26 wells with minimum mean concentrations of cations and anions, while cluster III included the wells with the highest concentrations in the water quality parameters. Cluster II included eight wells with intermediate concentrations. Azraq Area-2 wells are clustered into three groups. Cluster I includes seven wells with lowest water quality (highest concentrations); cluster II includes 12
\end{abstract}


wells and exhibits the lowest concentrations of ions and cluster III includes five wells that show intermediate ions concentrations. The interpretation indicated that the primary factors controlling the groundwater chemistry of Azraq and Harrana appeared to be dissolution processes of the carbonate rocks containing traces of evaporitic minerals, ion exchange and reversal ion exchange processes. Moreover, the water quality in the study areas is not suitable for drinking purposes.

\section{Keywords}

Groundwater, Hydrochemistry, Water Quality, Statistical Analysis, Oil Shale

\section{Introduction}

The current investigation aims at interpreting the different geochemical processes affecting the genesis of the water resources at the Harrana and Azraq Basins and defining the inter-relationship between the water resources and the oil shale deposits. Moreover, water quality characteristics will be defined for drinking purposes. The hydrochemistry of the collected groundwater samples represents a signature that reflects the sum of all physical and chemical processes and reactions that affected the water characteristics from the time of infiltration until reaching the aquifer. This study focuses on two locations (Harrana BasinArea-1 and Azraq Basin-Area-2) based on the concessional blocks explored by Jordan Oil Shale Company (JOSCO) for oil shale deposits. Area-1 is located about $35 \mathrm{~km}$ southeast of Amman City covering an area of $1714 \mathrm{Km}^{2}$, whereas, Area-2 is located $100 \mathrm{~km}$ east-southeast of Amman covering about $315 \mathrm{Km}^{2}$. They are located within the coordinates $36^{\circ} 20^{\prime}-36^{\circ} 50^{\prime}$ longitude and $31^{\circ} 45^{\prime}$ $31^{\circ} 25^{\prime}$ latitude, and coordinates $37^{\circ} 02^{\prime} \mathrm{E}-37^{\circ} 15^{\prime} \mathrm{E}$ longitude and $31^{\circ} 45^{\prime}-31^{\circ} 37^{\prime}$ longitude respectively (Figure 1).

\section{Geological Setting}

Jordan lies in the northwestern part of the Arabian Plate. The structures and sedimentation were controlled by the tectonic evolution with respect to the configuration of the Arabian Plate [1]. Marine conditions prevailed during the Cretaceous to Late Eocene and ended when the region underwent uplift. It was then subjected to regional faulting, which occurred mainly along rejuvenated old faults and pre-existing zones of weaknesses [2].

The regional dip direction of the strata in the study area is about $6^{\circ}$ towards the northeast [3], and follows the topography from the western mountains in the west towards east as shown by the mid resolution Aster Satellite Image (Figure 2). As indicated in Figure 2, the study area is affected by the extension of the major fault systems of Zarka Main and Swaqa Faults. In addition, NW-SE regional faults such as Fuluk, Ramtha-Wadi Sirhan, Amra and Wadi Dabi faults bounded Azraq and Harrana Basins and play as boundary faults.

Generally, the oil shale deposits of Jordan are classified as bituminous 


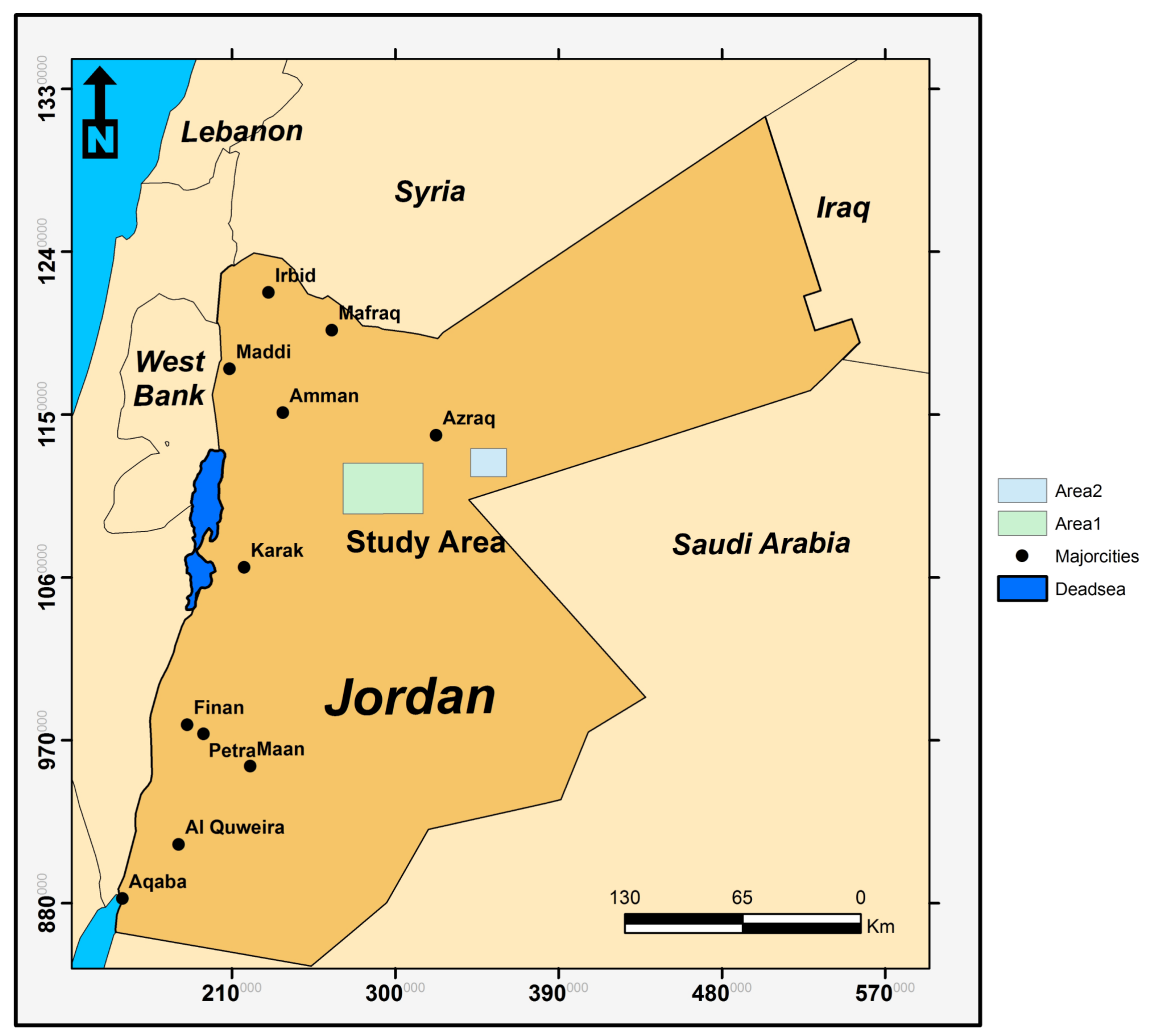

Figure 1. Location map of the two study areas, Area-1 and Area-2.

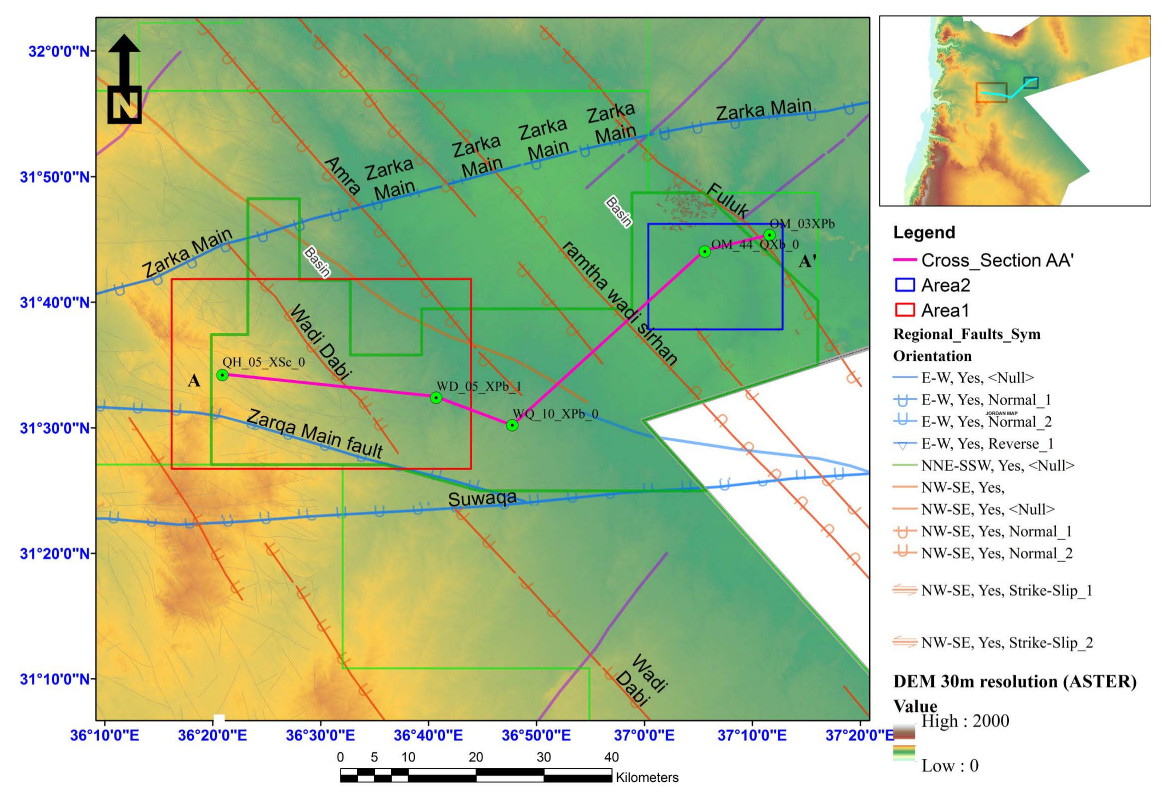

Figure 2. Satellite image and the major faults affecting the study areas.

limestones and marls. The geological, lithological, geochemical and economical aspects of these deposits have been subjected to intensive investigations by many researchers [4] [5] [6] [7] [8]. The geological position of the different rock formations within the stratigraphy column in the study area (oldest to youngest) are studied by many investigators [9]-[14] and are summarized in the geological 
cross section developed from the drilled wells in the area (Figure 3). The cross section A-A', was gathered for this study from JOSCO wells data files after signing agreement with the company to access their data files. The cross section shows correlation between QH_05, WD_05, WQ-10, OM-44 and OM-03 from east to west across Harrana and Azraq Basins. The location of this cross section is shown in the map (Figure 2) which includes the main regional faults that affect the area.

The wells shown in Figure 3 have been drilled with the aim to investigate the oil shale within the MCM. Therefore, the final depth of the holes was ended as shown in the drawing when it reached the water bearing strata of ASL.

\section{Materials and Methods}

The groundwater samples have been collected from the Amman Silicified Limestone (ASL) and overburden (OB) wells to perform laboratory analyses for the determination of baseline/background water quality and to determine the source of groundwater. Sixty water samples have been collected during the period 2011 to 2015. The collected samples were analyzed for their hydrochemical characteristics in the Laboratories of Water Authority of Jordan and Alcontrol Laboratory in UK. Sampling procedures and in situ field analyses were conducted according to the standard methods of water sampling and analyses [15]. The collected water samples from the different wells are given in Table 1. It is worth mentioning that samples with the High Grade Zone (HGZ) rich oil shale within Muwaqqar Chalk Marl Formation (MCM) and ASL (lean or no oil shale) were mostly pumped samples.

\section{Groundwater Quality}

Natural waters always contain variable amounts of dissolved salts. These are derived from the interaction between the water and various solids, liquids and gases as the groundwater makes its way from its recharge area to discharge area

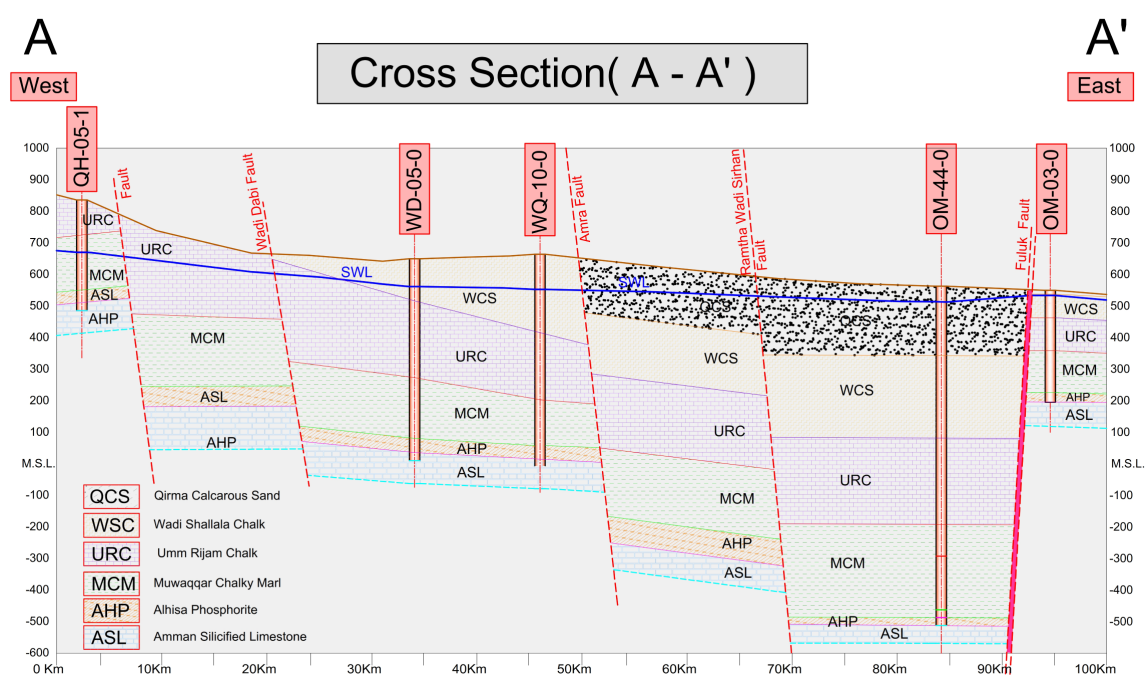

Figure 3. EW cross section in Area-1 and Area-2. 
Table 1. Assigned station/sample name for water samples (used to identify data on graphs and provide unique information for each sample).

\begin{tabular}{|c|c|c|c|}
\hline Well name & Geology & Sampling method & Assigned station/sample name \\
\hline QH_03_XPb_0 & $\operatorname{mix}$ & Bailer & QH_03_0_mix_B_082312 \\
\hline QH_03_XPb_0 & ASL & Pump & QH_03_0_ASL_P_082412 \\
\hline QH_04_XSb_0 & $\operatorname{mix}$ & Bailer & QH_04_0_mix_B_031412 \\
\hline QH_05_XSc_0 & HGZ & Bailer & QH_05_0_HGZ_B_101311 \\
\hline QH_05_XSc_0 & HGZ & Pump & QH_05_0_HGZ_P_102911 \\
\hline QH_05_XSc_1 & ASL & Bailer & QH_05_1_ASL_B_101311 \\
\hline QH_05_XSc_1 & ASL & Pump & QH_05_1_ASL_P_101411 \\
\hline QH_06_XSb_0 & HGZ & Bailer & QH_06_0_HGZ_B_110211 \\
\hline QH_06_XSb_0 & HGZ & Bailer & QH_06_0_HGZ_B_111011 \\
\hline QH_06_XSb_0 & HGZ & Pump & QH_06_0_HGZ_P_111211 \\
\hline QH_07_XTb_0 & $\operatorname{mix}$ & Bailer & QH_07_0_mix_B_030611 \\
\hline QH_07_XTb_0 & $\operatorname{mix}$ & Bailer & QH_07_0_mix_B_122811 \\
\hline QH_07_XTb_0 & ASL & Pump & QH_07_0_ASL_P_011012 \\
\hline QH_08_XPb_0 & ASL & Pump & QH_08_0_ASL_P_082213 \\
\hline $\mathrm{QH} \_08 \_X P b \_0$ & HGZ & Pump & QH_08_0_HGZ_P_082213 \\
\hline QH_11_XPb_0 & ASL & Pump & QH_11_0_ASL_P_031011 \\
\hline QT_10_XTb_0 & ASL & Pump & QT_10_0_ASL_P_040413 \\
\hline QT_10_XTb_0 & HGZ & Pump & QT_10_0_HGZ_P_040413 \\
\hline WD_07_XPb_0 & ASL & Pump & WD_07_0_ASL_P_121113 \\
\hline WD_07_XPb_0 & HGZ & Pump & WD_07_0_HGZ_P_121213 \\
\hline WD_27_XTb_0 & HGZ & Pump & WD_27_0_HGZ_P_041213 \\
\hline WD_29_XTb_0 & ASL & Pump & WD_29_0_ASL_P_051213 \\
\hline WD_29_XTb_0 & HGZ & Pump & WD_29_0_HGZ_P_051313 \\
\hline OM_05_XPb_0 & OB & Pump & OM_05_0_OB_061313 \\
\hline OM_05_XPb_0 & HGZ & Pump & OM_05_0_HGZ_P_061413 \\
\hline OM_05_XPb_0 & ASL & Pump & OM_05_0_ASL_P_061413 \\
\hline OM_38_XQb_1 & ASL & Pump & OM_38_1_ASL_P_112914 \\
\hline OM_38_XQb_1 & OB & Pump & OM_38_1_OB_P_112914 \\
\hline OM_39_XQb_0 & ASL & Pump & OM_39_0_ASL_P_11114 \\
\hline OM_39_XQb_0 & OB & Pump & OM_39_01_OB_P_11114 \\
\hline OM_41_XQb_0 & ASL & Pump & OM_41_01_ASL_P_080514 \\
\hline OM_41_XQb_0 & OB & Pump & OM_41_01_OB_P_080514 \\
\hline OM_43_XQb_0 & ASL & Pump & OM_43_0_ASL_P_043014 \\
\hline OM_44_QXb_0 & ASL & Pump & OM_44_0_ASL_P_051714 \\
\hline OM_44_QXb_0 & OB & Pump & OM_44_0_OB_P_051714 \\
\hline OM_46_XQb_0 & ASL & Pump & OM_46_0_ASL_P_122114 \\
\hline
\end{tabular}




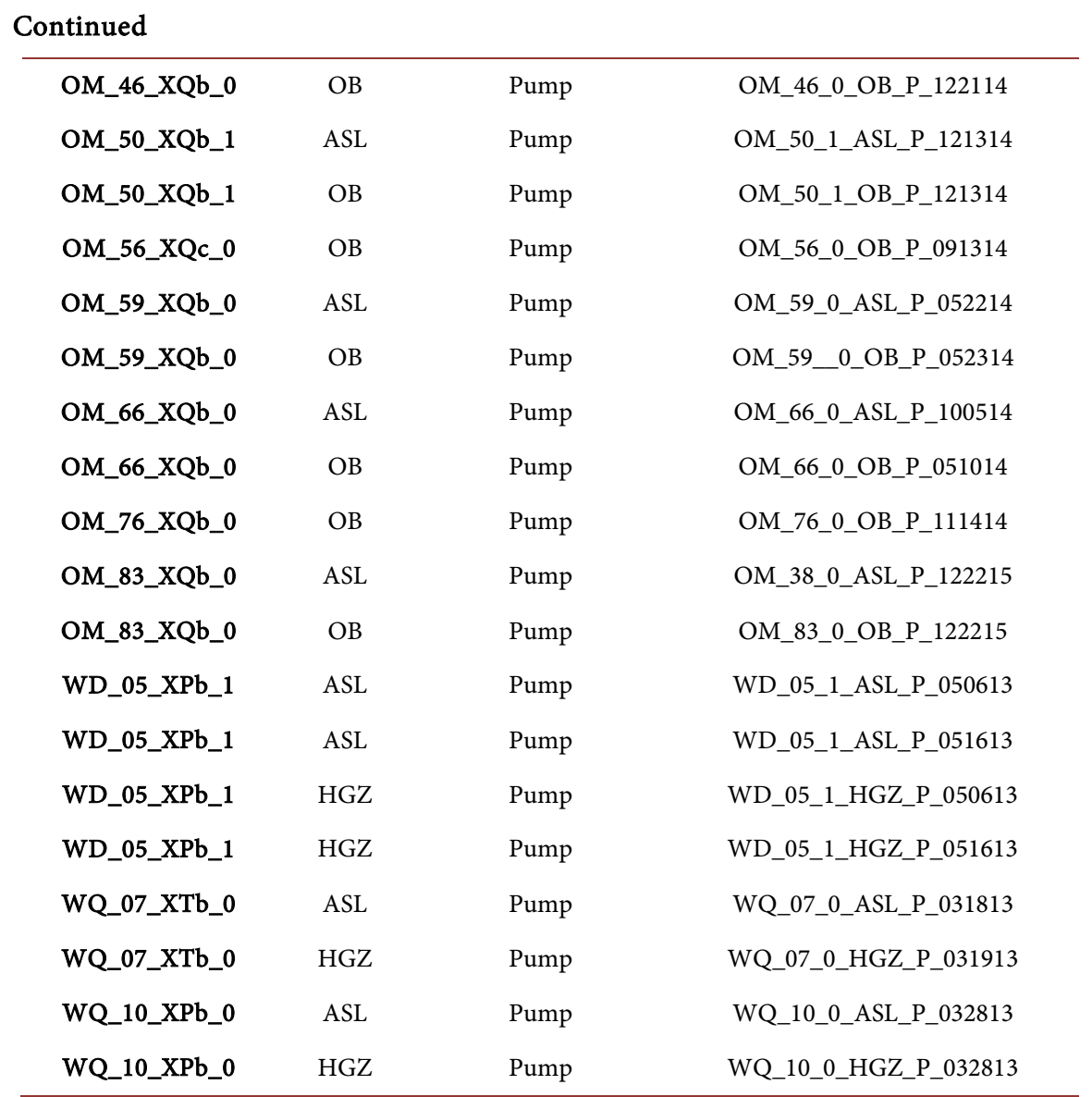

[15]. More than $90 \%$ of the dissolved solids in groundwater can be attributed to eight ions: $\mathrm{Na}^{+}, \mathrm{Ca}^{2+}, \mathrm{K}^{+}, \mathrm{Mg}^{2+}, \mathrm{SO}_{4}^{2-}, \mathrm{Cl}^{-}, \mathrm{HCO}_{3}^{-}$and $\mathrm{CO}_{3}^{2-}$ [16]. The chemical properties are discussed below:

1) $\mathrm{Ca}^{2+}$

Calcium is one of the most abundant cation in Area-1 whereas the minimum value $4.42 \mathrm{mg} / \mathrm{L}$ and maximum value $887.1 \mathrm{mg} / \mathrm{L}$ with an average of $168.33 \mathrm{mg} / \mathrm{L}$ for ASL and average of 138.34 for overburden (OB). On the other hand, in Area-2 the minimum value $7.02 \mathrm{mg} / \mathrm{L}$ and maximum value $1865.6 \mathrm{mg} / \mathrm{L}$ and with an average of value of $958.6 \mathrm{mg} / \mathrm{L}$ for ASL and $857.99 \mathrm{mg} / \mathrm{L}$ for OB. In general, concentration of this ion mostly prohipited the untilization of this water for drinking purposes hence, the limit of $\mathrm{Ca}$ for drinking water is specified as maximum permissible limit about $200 \mathrm{mg} / \mathrm{L}$ [17].

2) $\mathrm{Mg}^{2+}$

Magnesium is found in considerable amounts, next to calcium and sodium ion concentrations in the groundwater, ranging from $4.83 \mathrm{mg} / \mathrm{L}$ to $112.13 \mathrm{mg} / \mathrm{L}$ with average value of $62.17 \mathrm{mg} / \mathrm{L}$ for ASL and average of $59.6 \mathrm{mg} / \mathrm{L}$ for OB in Area-1. In Area-2 the concentration ranging from $5.28 \mathrm{mg} / \mathrm{L}$ to $1670.5 \mathrm{mg} / \mathrm{L}$ with average value of $626.57 \mathrm{mg} / \mathrm{L}$ of ASL and $584.37 \mathrm{mg} / \mathrm{L}$ of OB. Generally, magnesium is derived mainly from the dissolution processes of dolomite and magnesite [18]. The maximum acceptable limit of $\mathrm{Mg}^{2+}$ for drinking water is 50 $\mathrm{mg} / \mathrm{L}[17]$. 


\section{3) $\mathrm{Na}^{+}$}

The concentration of sodium ranges from $5.49 \mathrm{mg} / \mathrm{L}$ and $681 \mathrm{mg} / \mathrm{L}$ and with an average value of $238.30 \mathrm{mg} / \mathrm{L}$ for ASL and an average of $243.5 \mathrm{mg} / \mathrm{L}$ for OB in Area-1. On the other hand, in Area- 2 the concentration of sodium ranges between 1510 to $40,000 \mathrm{mg} / \mathrm{L}$ with an average of $11562 \mathrm{mg} / \mathrm{L}$ in the $\mathrm{OB}$ and 23287 $\mathrm{mg} / \mathrm{L}$ for ASL, which represents the most dominant cation in the study area. The maximum limit of $\mathrm{Na}^{+}$for drinking water is specified as $200 \mathrm{mg} / \mathrm{L}$ [17].

4) $\mathrm{K}^{+}$

Potassium is the least abundant major cation in the groundwater resources in both Areas 1and 2. Its concentration ranging between $0.2 \mathrm{mg} / \mathrm{L}$ and $28 \mathrm{mg} / \mathrm{L}$ and with an average of $10.28 \mathrm{mg} / \mathrm{L}$ for ASL and of $7.2 \mathrm{mg} / \mathrm{L}$ for $\mathrm{OB}$, and varying between $25 \mathrm{mg} / \mathrm{L}$ and $1413.6 \mathrm{mg} / \mathrm{L}$ with an average of $772.6 \mathrm{mg} / \mathrm{L}$ for ASL and average of 584.4 for OB. The low concentration of potassium is attributed to geochemical processes affected its dissolution of feldspars and cation exchange/ adsorption/desorption with clay minerals [19]. $200 \mathrm{mg} / \mathrm{L}$ is the maximum permissible limit for potassium in drinking water [17].

5) $\mathrm{HCO}_{3}^{-}$

The bicarbonate contents in the study Area-1, ranging between $3.29 \mathrm{mg} / \mathrm{L}$ and $549.6 \mathrm{mg} / \mathrm{Land}$ with an average value of $313 \mathrm{mg} / \mathrm{L}$ for ASL and an average value of $302 \mathrm{mg} / \mathrm{L}$ for OB. Bicarbonate values in study Area-2 range between $510 \mathrm{mg} / \mathrm{L}$ and $4330 \mathrm{mg} / \mathrm{L}$. Generally, the bicarbonate and carbonate contents represent the alkalinity and their distribution is a function of $\mathrm{pH}$-value of the water sample.

6) $\mathrm{Cl}^{-}$

The maximum value of $\mathrm{Cl}^{-}$content is $1065.9 \mathrm{mg} / \mathrm{L}$ while the minimum value is $69.8 \mathrm{mg} / \mathrm{L}$, with an average value of $461 \mathrm{mg} / \mathrm{L}$ for ASL and with an average value of $508.4 \mathrm{mg} / \mathrm{L}$ for $\mathrm{OB}$ in Study Area-1. The Maximum value for $\mathrm{Cl}^{-}$is $65,500 \mathrm{mg} / \mathrm{L}$ for ASL while the minimum value is $2910 \mathrm{mg} / \mathrm{L}$ for OB in study Area-2. The main source of chloride in groundwater is attributed to the dissolution processes of the traces of evaporites and most probably ancient entrapped seawater [20] [21]. The maximum acceptable limit of chloride for drinking water is $250 \mathrm{mg} / \mathrm{L}$ [17].

7) $\mathrm{SO}_{4}^{2-}$

The relative high concentration of sulfate in the groundwater resources in both Areas 1 and 2 is attributed to the dissolution processes of the evaporitic minerals and in some cases to the oxidation process of the pyrite mineral disseminated in the oil shale deposits. In addition, agricultural activities are also considered as another source of sulfate [21] [22]. The maximum permissible limit for sulfate in drinking water is specified to be $250 \mathrm{mg} / \mathrm{L}$ [17]. The sulfate content ranges from $4.36 \mathrm{mg} / \mathrm{L}$ to $695 \mathrm{mg} / \mathrm{L}$ with mean value of $204 \mathrm{mg} / \mathrm{L}$ for ASL and $251 \mathrm{mg} / \mathrm{L}$ for OB in Area-1. In Area-2sulfate range from $20 \mathrm{mg} / \mathrm{L}$ to $4200 \mathrm{mg} / \mathrm{L}$ for $\mathrm{OB}$ and $20 \mathrm{mg} / \mathrm{L}$ to $3592 \mathrm{mg} / \mathrm{L}$ for ASL.

\section{Hydrogeochemistry}

The chemical composition of groundwater is primarily dependent on the geolo- 
gy as well as on the geochemical processes, which take place to form groundwater facies. Facies are identifiable parts of different nature belonging to any genetically related body or system. Hydrochemical facies are distinct zones that have cation and anion concentrations describable within defined composition categories [23]. Aquachem (AQUACHEM 2014 ver.2) is water quality software with functionality for graphical and numerical analysis and modeling of water quality data. The hydrochemical data of the analyzed groundwater samples at Harrana and Azraq Basins interpreted using different graphical representation diagrams such as Piper diagram, which describes the relative compositions of cations and anions, and Durov diagram that represents the geochemical process.

Piper Diagram composed of anion and cation triangles with a diamond shape between them used to replot the analysis [24]. The diagram contains two triangular charts for depicting the proportions of cations and anions expressed in meq/L. The Aquachem software 2014 ver. 2 (Waterloo Hydrogeologic, Inc., 2014) was used for plotting this diagram to display the relative concentrations of the different ions in water samples in the study area. The data points in the two base triangles are projected onto an adjacent diamond grid. Furthermore, it is used to assess the Hydrogeochemical facies. Piper trilinear diagram and according to [25] classified the water into seven types.

Ionic concentrations for Harrana and Azraq samples were plotted in a Piper diagram to evaluate the geochemical characteristics of the sampled groundwater. Generally, the predominant anion and cation in both periods are chloride and sodium, respectively. All ions concentrations and the outputs in $\mathrm{mg} / \mathrm{L}$ of the analyzed groundwater samples collected from study areas are plotted on Piper diagram.

The water quality characteristics of the ASL and HGZ intervals are examined to identify differences that might indicate that the waters in the two intervals are separated by less permeable intervals and do not mix. A Piper Diagram for all the samples from the ASL, HGZ and OB intervals for Area-1 and Area-2 are plotted in Figure 4.

These diagrams reveal that there are three different groundwater types were identified in the study areas of Harrana and Azraq Basins are:

1) The first type of hydrochemical facies shows that 28 out of 31 of groundwater samples (90.32\%) collected from Harrana lied in the Class-E as Earth Alkaline water with increase portion of alkalis with prevailing sulfate and chloride $\left(\mathrm{Ca}^{2+}-\mathrm{Mg}-\mathrm{Na}-\mathrm{Cl}-\mathrm{SO}_{4}\right)$. It is clear that the major ions falling within mixed zone (No cation-anion exceed 50\%) also, demonstrating the dominance of alkaline earths over alkali (i.e., $\mathrm{Ca}^{2+}+\mathrm{Mg}^{2+}>\mathrm{Na}^{+}+\mathrm{K}^{+}$) and strong acidic anions over weak acidic anions (i.e., $\mathrm{Cl}^{-}+\mathrm{SO}_{4}^{2-}>\mathrm{HCO}_{3}^{-}$).

2) The second type of hydrochemical facies shows that 20 out of 20 of groundwater samples i.e., $100 \%$ of Azraq groundwater samples lies in the Class-G. In addition, 5 out of 31 samples in Harrana which represent $16.12 \%$ of the total samples in Harrana fall in the same class as Alkaline water with prevailing sulfate and chloride $\left(\mathrm{Na}^{+}-\left(\mathrm{K}^{+}\right)-\mathrm{Cl}^{-}-\mathrm{SO}_{4}^{2-}\right)$. 


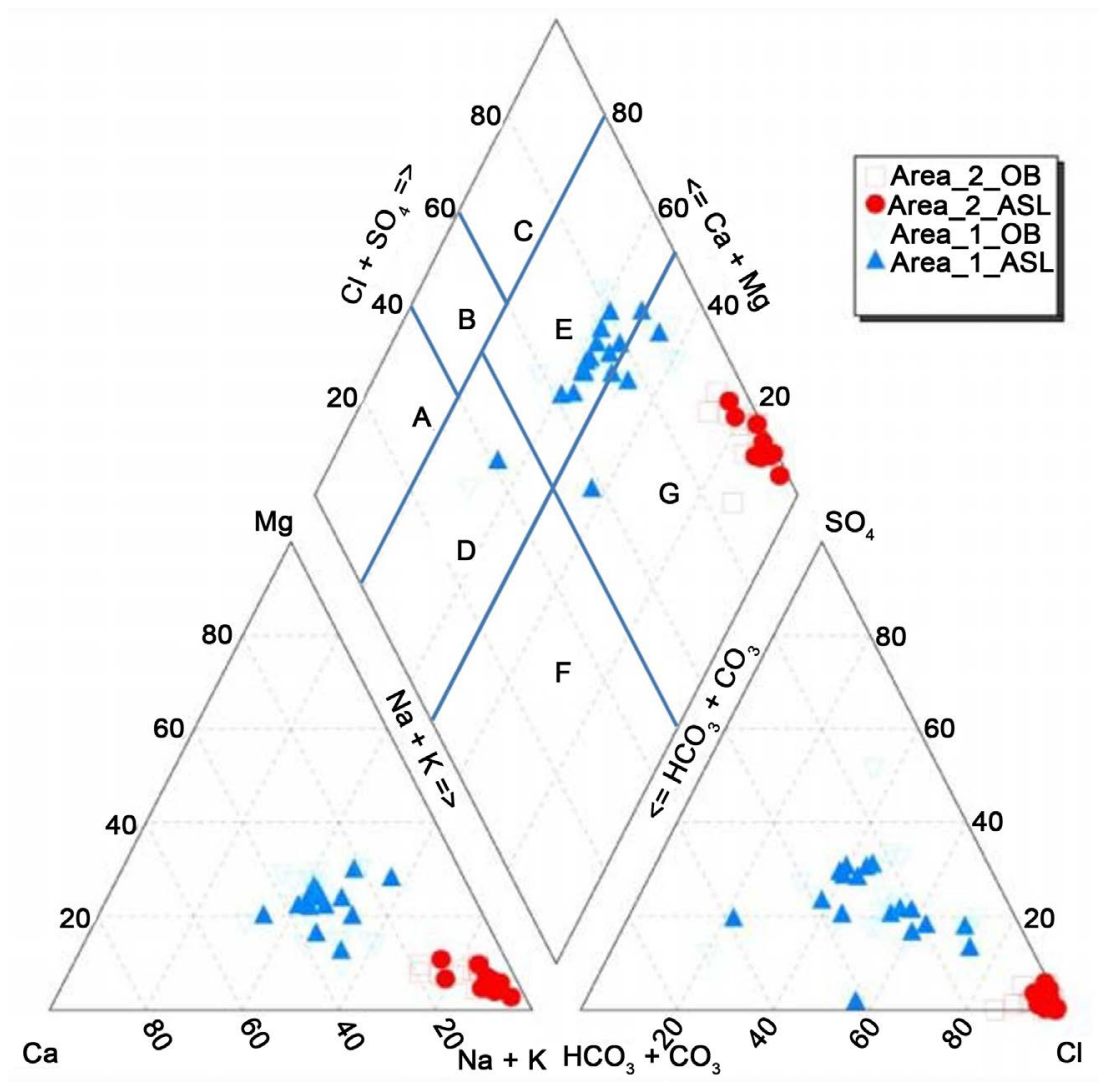

Figure 4. Piper Trilinear diagram classifying major hydrochemical facies for ASL and OB groundwater samples in Area-1 and Area-2 [25].

3) Two analyzed sample represents about (6.45\%) taken from Harrana Basins well WQ-07, shifting the results to the middle of piper plot to fall under zone of weak acids $\left(\mathrm{HCO}_{3}^{-}\right)$exceeds strong acids. Which means that a third type of hydrochemical facies located in class-D as Earth Alkaline water with increasing portion of alkalis with prevailing bicarbonate $\left(\mathrm{Ca}^{2+}-\mathrm{HCO}_{3}^{-}\right)$.

Durov Diagram is a composite plot consisting of 2 ternary diagrams where the cations of interest are plotted against the anions of interest (data is normalized to $100 \%$ ); sides form a binary plot of total cation vs. total anion concentrations; expanded version includes TDS ( $\mathrm{mg} / \mathrm{L}$ ) and $\mathrm{pH}$ data added to the sides of the binary plot to allow further comparisons. The main purpose of the Durov diagram [26] is to cluster the data points indicating the samples with similar chemical composition as well as to reveal a useful relationships and properties for a large sample groups. This method has been adopted in order to evaluate the water types from the geochemical process that could have been affected the groundwater type also to present the total or absolute concentrations of two selected parameters such as total cation or ion concentration, $\mathrm{pH}$ or TDS.

These Durov diagrams in Figure 5 reveal that there are four geochemical processes that could affect the water genesis for both study areas.

1) Most of groundwater samples about 16 out of 20 ASL samples $(80.0 \%)$ and 16 out 21 OB (76.19\%) samples of Area-1 are plotted in field 5. No dominant anion or cation, indicates water exhibiting simple dissolution or mixing. 


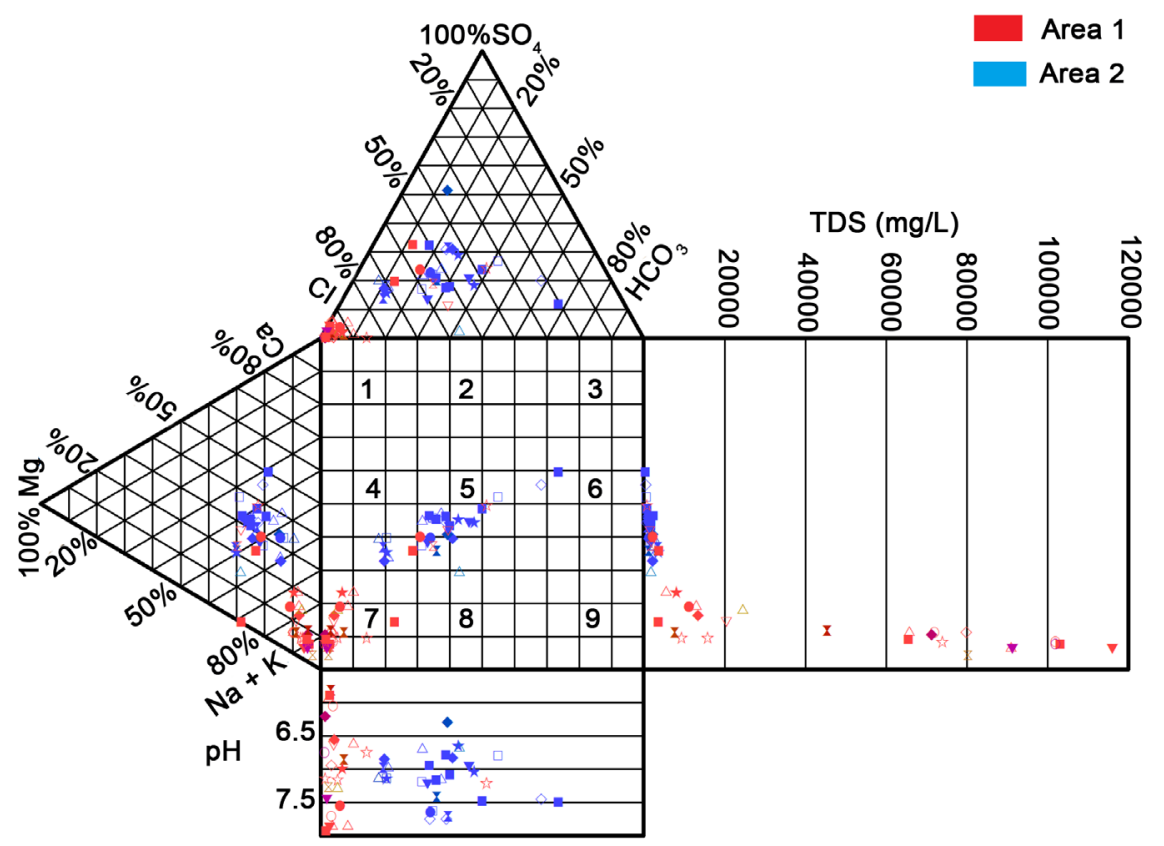

Figure 5. Durov plot depicting Hydrochemical processes involved [26].

2) Some of groundwater samples about $10 \%$ of ASL and $23.8 \%$ of the OB for area are plotted in field 4 , which $\mathrm{Ca}$ and $\mathrm{SO}_{4}$ dominant, therefore mixed water or water exhibiting simple dissolution may be indicated.

3) The rest of the samples $10 \%$ for ASL and $9.5 \%$ for OB for Area-1 plotted in field 6. $\mathrm{SO}_{4}$ dominant or anion discriminate and $\mathrm{Na}$ dominant; is a water type that is not frequently encountered and indicates probable mixing or uncommon dissolution influences.

4) All the samples from Area-2 are plotted in field 7. $\mathrm{Cl}$ and $\mathrm{Na}$ dominant is frequently encountered unless cement pollution is present. Otherwise, the water may result from reverse ion exchange of $\mathrm{Na}-\mathrm{Cl}$ waters.

\section{Statistical Analysis}

Generally, groundwater wells penetrating either the same aquifer or different aquifers have different water quality characteristics type [23]. The groundwater quality depends not only on natural factors such as the lithology of the aquifer, the quality of recharged water and the type of interaction between water and aquifer, but also on human activities, which can alter these groundwater systems either by polluting them or by changing the hydrological prevailing conditions [27].

Statistical analyses conducted by applying factor analysis with varimax rotation on standardized data and factor loading of the variables were obtained. Hierarchical cluster analysis was used to group Area-1 and Area-2 wells of Harrana and Azraq, respectively. Complete linkage was used depending on Pearson distance. 


\subsection{Methods of Analysis}

The physical tests, which include total dissolved solids and electrical conductivity, and the chemical tests, which include $\mathrm{pH}$, total hardness, calcium, magnesium, sodium, potassium, sulfate, nitrate, and chloride, were conducted according to the standard methods [28]. Factor analysis was conducted to explain the outline of groundwater quality variation according to the measured parameters. Statistical analysis was also used to classify the studied wells according to their water quality using complete linkage cluster analysis.

\subsubsection{Factor Analysis}

1) Factor Analysis for the water parameters of the wells in Area quality 1

Factor analysis extracted four factors from the measured water quality parameters to represent water quality variation in the study area. The analysis was conducted using the rotation technique depending on Eigen values of 1 or more [29]. The extracted four factors represented $70.38 \%$ of the variation in groundwater quality within the studied Area-1. The correlation of the parameters with the factors is considered significant when it exceeded the radius of the balance circle, which is equal to 0.50 calculated from the square root of the division of number of factors by the number of parameters [30].

The first factor (Factor 1) represents $42.446 \%$ of the trace of the correlation matrix. This factor shows significant correlation with magnesium, sulfate, chloride, sodium and calcium ions also the hardness and the TDS and electric conductivity was loaded significantly. Factor 2 represents $11.426 \%$ of the total variance in groundwater quality within the study area. Strontium, Aluminum, Silica and BTEX were loaded on it significantly (Figure 6). In addition, the figure exhibits weak correlation between Silica from one side versus strontium, boron and BTEX from the other side. According to the angle between the parameters vectors which is weak when it is about 90 degrees, strong when it is small and inverse when reach 180 degrees and around it.

Factor 3 represents $8.483 \%$ of the total variance in groundwater quality. Potassium, bicarbonate and manganese was loaded significantly on it (Figure 7). In addition, this figure shows strong correlation between potassium, bicarbonate ions, both correlate weakly with sulfate.

Factor 4 represents $8.025 \%$ of the total variance in groundwater quality of the studied area, arsenic, $\mathrm{pH}$ and barium loaded significantly (Figure 8 ). The figure shows strong correlation between barium and $\mathrm{pH}$, and weak correlation with BTEX and boron.

2) Analysis for the water quality parameters of the wells in Area-2

The four factors of the factor analysis extracted according to Eigen values $(>1)$ for Area-2 wells. The first factor accounts for $40.828 \%$ the variability in water quality, whereas the second factor assists in describing water quality in Formation of Area-2 wells within 16.234\%. Cations including $\mathrm{Na}, \mathrm{Mg}$, Ca and $\mathrm{K}$ with anions including $\mathrm{Cl}$ and $\mathrm{SO}_{4}$ were loaded significantly on factor 1 .

Figure 9 indicates a strong relationship among the cations and anions. Phosphate chromium and manganese loaded significantly on factor 2 . 


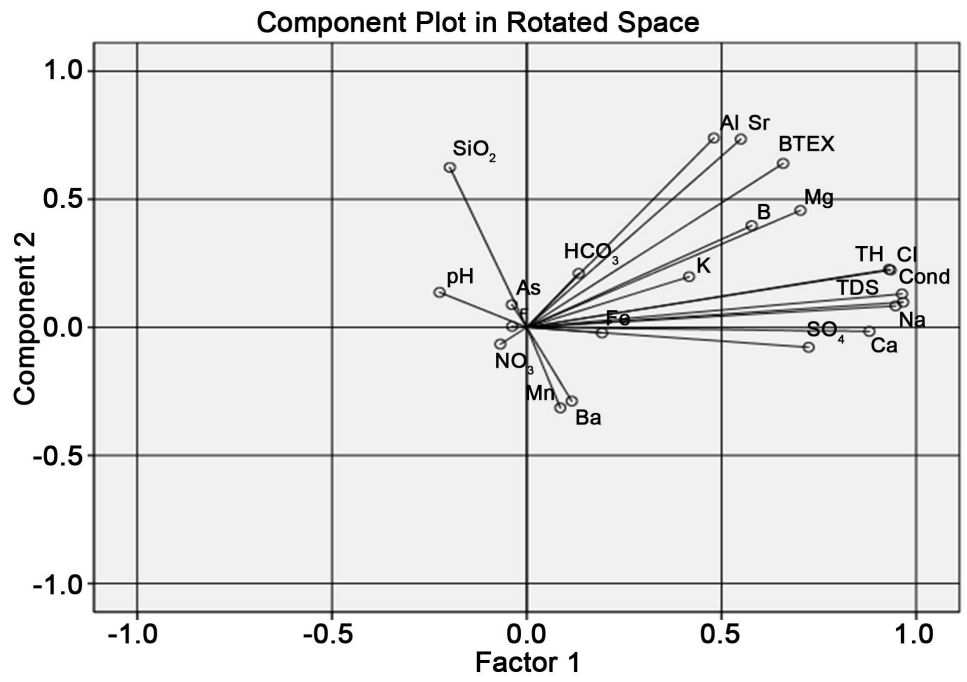

Figure 6. The weights of factor 1 parameters versus factor 2 for Area-1.

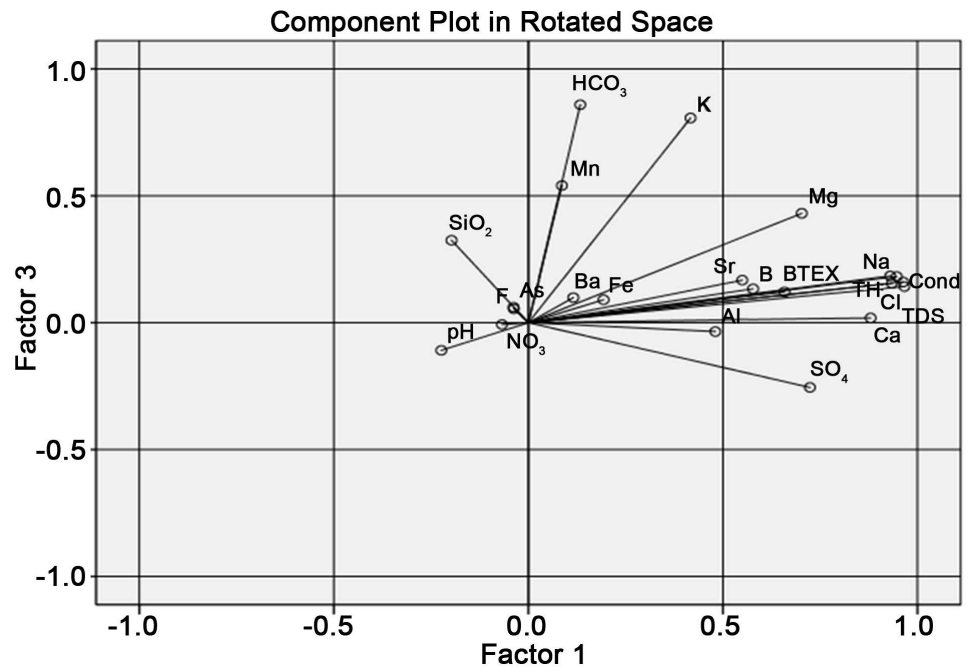

Figure 7. The weights of factor 1 parameters versus factor 3 for Area-1.

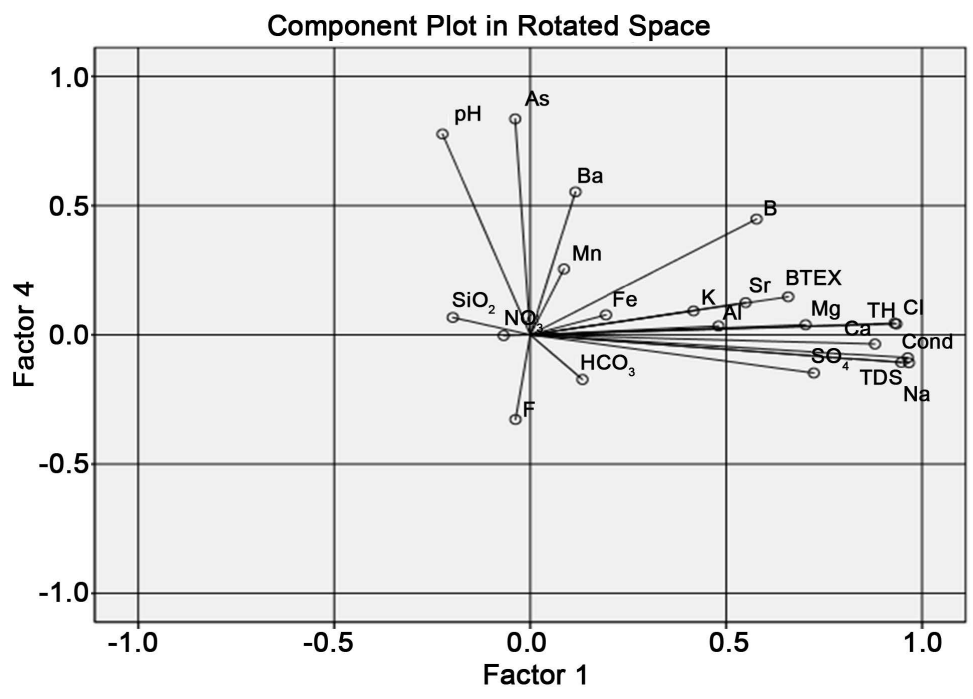

Figure 8. The weights of factor 1 parameters versus factor 4 parameters for Area-1. 


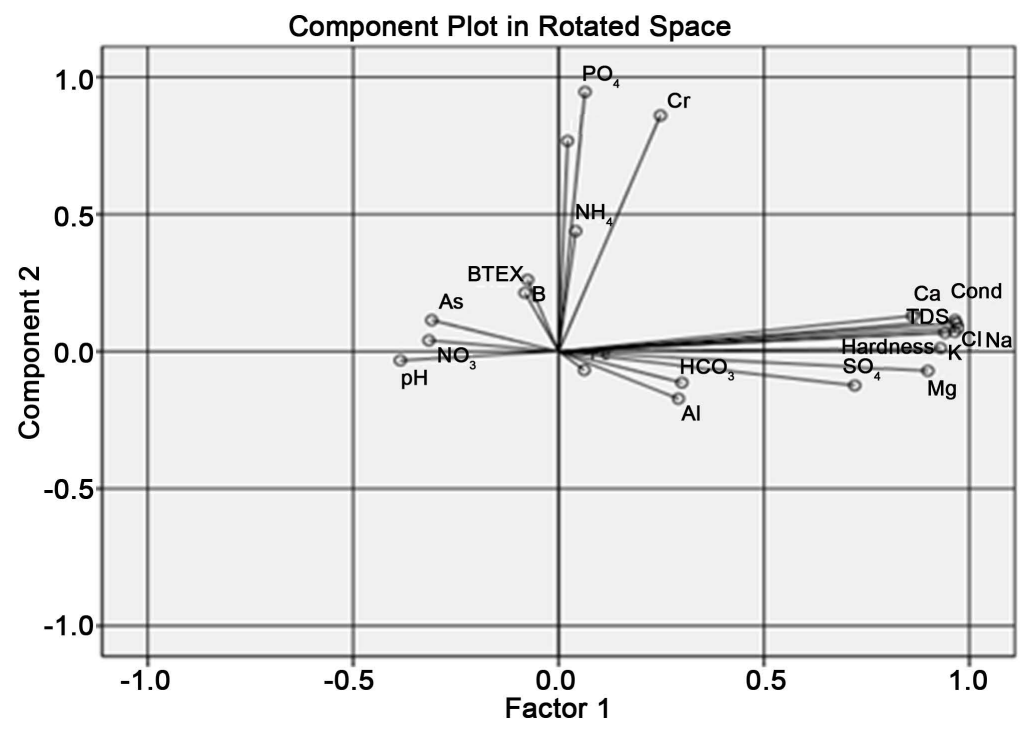

Figure 9. The weights of factor 1 parameters versus factor 2 for Area-2.

Factor 3 denoted $9.55 \%$ of the total variance in groundwater quality within the study area. Ammonia, $\mathrm{pH}$ and boron were loaded on it significantly (Figure 10). The figure also shows direct strong correlation between ammonia and boron and negative correlation with $\mathrm{pH}$. Factor 4 represents the geology of the studied area with $6.636 \%$ of the total variance in ground water quality. Aluminum and BTEX was loaded significantly on it. They are both negatively correlated with each other (Figure 11).

\subsubsection{Cluster Analysis}

Cluster analysis is used to combine water quality parameters into homogenous groups from clustered sites. It is also possible to evaluate whether water quality samples at various locations can be combined into homogenous regions and/or geochemical processes.

1) Cluster analysis for the water quality parameters of Area-1

Figure 12 shows the results of cluster analysis for water quality of the Harrana wells in Area-1. Three clusters were obtained from this analysis. Cluster I had the largest number of wells of 21 with $58.3 \%$ and it includes two sub-clusters. Cluster II includes 13 wells (No. 6, 7, 10, 13, 14, 19, 23, 24, 25, 31, 33 and 34) with $36.1 \%$ of the studied wells and it includes two sub-clusters. The smallest cluster III includes two wells only (No. 9 and 28) and it represents $5.55 \%$ of the studied wells.

2) Cluster analysis for the water quality parameters of Area-2

The distribution of wells and the clusters are shown in Area-2 wells are classified into three clusters (Figure 13). Cluster I includes 10 wells (No. 6, 7, 10, 14, $15,16,17,21,22$ and 23 ), with $41.66 \%$. It attained the moderate concentrations of cations, anions, TDS, and conductivity between Cluster II and Cluster III. Cluster II includes twelve wells (No. 2, 4, 8 and 9) with $16.66 \%$. It has the highest concentration of cations, anions, TDS, and conductivity among the Area- 2 wells. The last cluster in Area-2 wells is Cluster III, this one has two sub clusters 


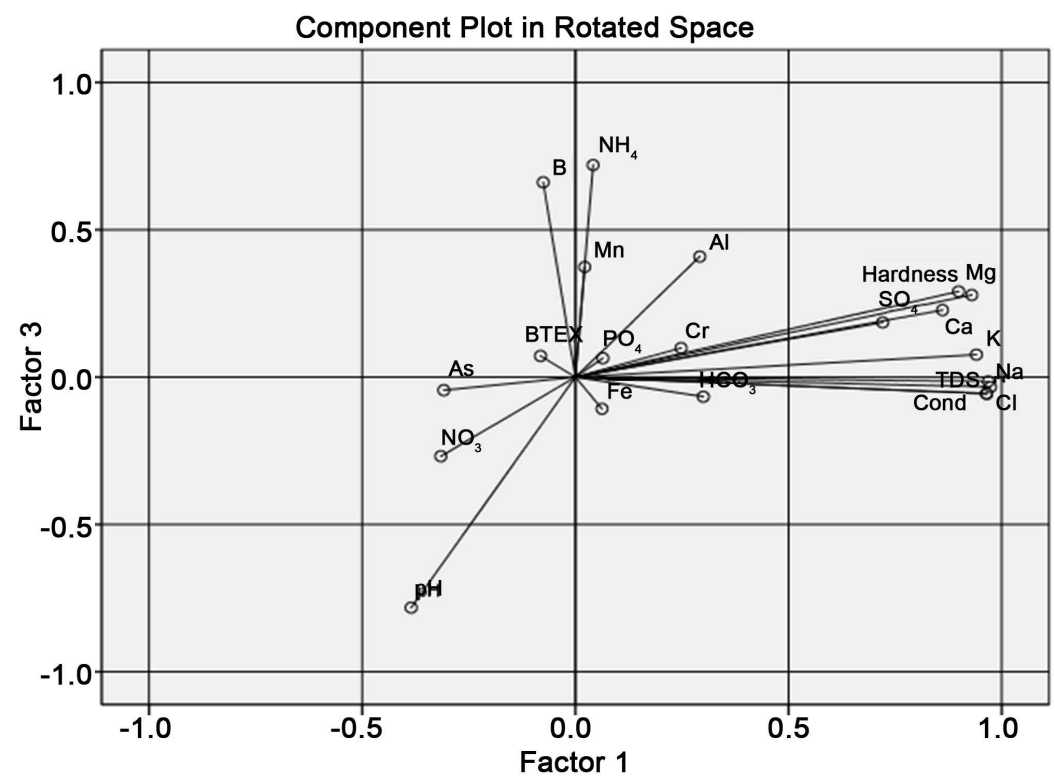

Figure 10. The weights of factor 1 parameters versus factor 3 for Area-2.

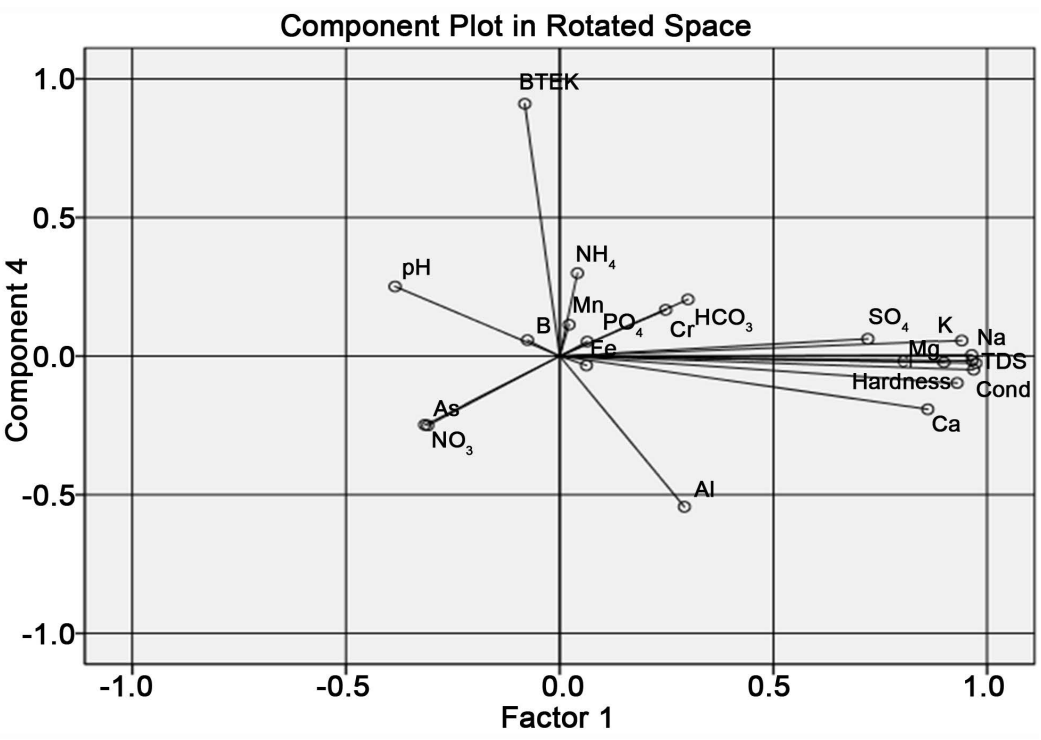

Figure 11. The weights of factor 1 parameters versus factor 4 parameters for Area-2.

include 10 wells (No. 1, 3, 5, 11, 12, 13, 18, 19, 20 and 24) which represented $41.66 \%$. This cluster has lowest concentration of cations, anions, TDS, and conductivity.

\section{Discussion and Conclusions}

Assessment of water samples from various methods for Area-1 and Area-2 indicated that groundwater in both areas was not suitable for drinking purposes, and the TDS, EC TH and fluoride concentrations were exceeding the permissible limits for human consumption, as per the standards of WHO. MCM and the overlying waters show no distinct geochemical characteristics when compared with ASL waters, implying that MCM did not act as a hydraulic seal. 


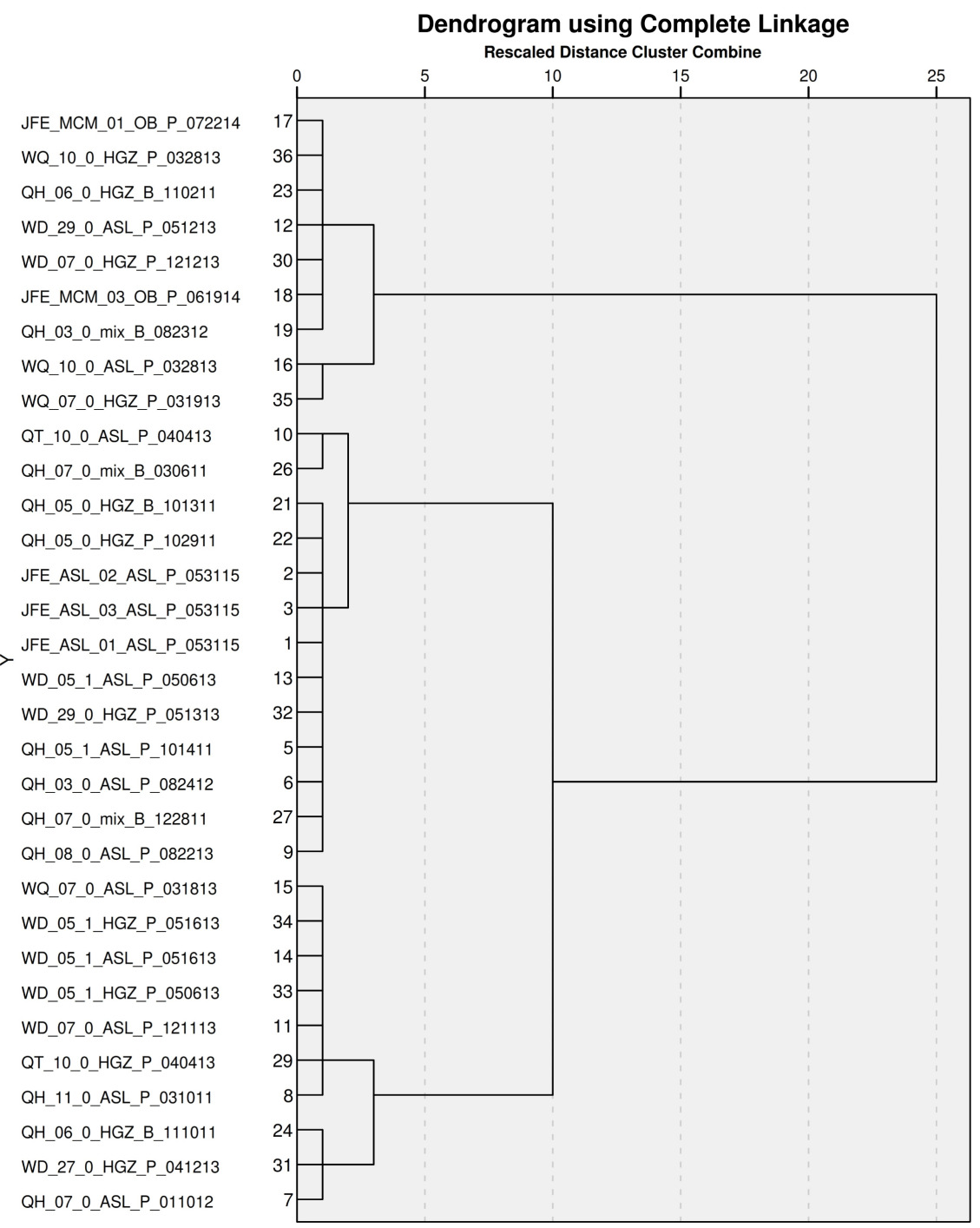

Figure 12. Hierarchical dendrogram cluster analysis of water quality parameters of the studied wells in Area-1.

Lateral changes (East-West) in water type can be identified in Harrana basins, while no preferred lateral changes can be distinguished in Azraq Basin. Three main facies revealed from the analysis of piper diagram as follows:

a) For earth alkaline water with enrichment in alkalis with prevailing sulfate and chloride (Ca-Mg-Na-Cl- $\mathrm{SO}_{4}$ ), these hydrochemical facies represent $90.32 \%$ of groundwater samples of Harrana basin.

b) For alkaline water with prevailing sulfate and chloride (Na-(K)-Cl-SO $)_{4}$, as strong acids $\left(\mathrm{Cl}\right.$ and $\left.\mathrm{SO}_{4}\right)$, facies represent $100 \%$ of Azraq groundwater samples.

c) For earth alkaline water with enrichment in alkalis with prevailing bicarbonate $\left(\mathrm{Ca}-\mathrm{HCO}_{3}\right)$, facies represent $6.45 \%$ of Harrana groundwater samples.

As inferred from the previous discussions, no major difference in water quality of the samples is found. Therefore, no difference in the HGZ and ASL water attributes, eliminating the possibility of isolation and probably the waters are separated by low permeability strata. 


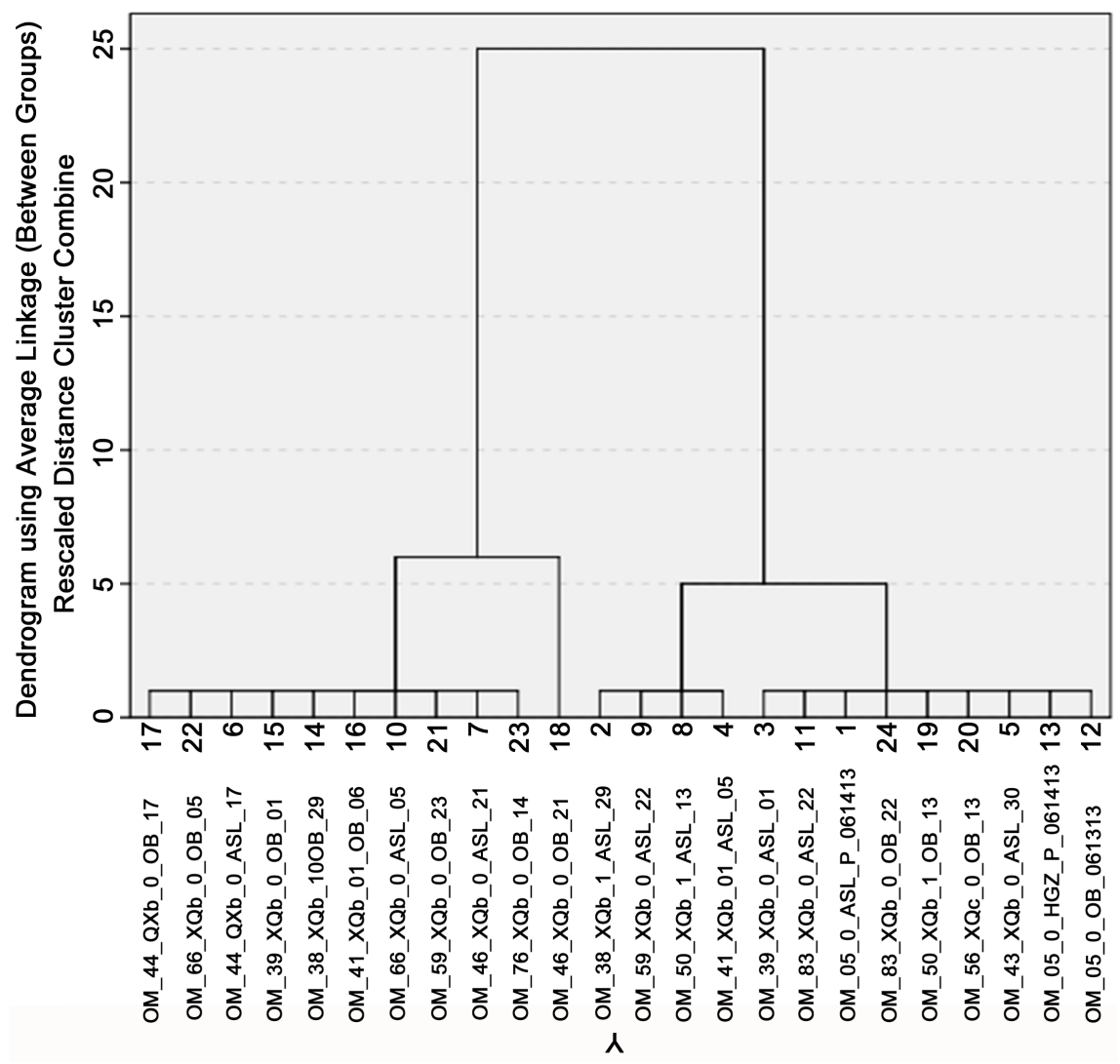

Figure 13. Hierarchical dendrogram cluster analysis of water quality parameters of the studied wells in Area-1 to the left and Area-2.

However, it is possible that there is isolation between some of the wells such as WQ-07 and QH-05 in Area-1. In Area-2 there are indications of possible isolation at OM_38, OM_39, and OM_41, and less substantial difference between the ASL and OB in the rest of the samples.

Most of the samples of Area-1 are in saturation equilibrium with the calcite and dolomite and under-saturation with anhydrite and gypsum. In Area-2 most of the samples area saturated with calcite and dolomite and undersaturated anhydrite and gypsum.

Most of the plotted samples for Area- 1 and Area-2 have $(\mathrm{Ca}+\mathrm{Mg})>\left(\mathrm{SO}_{4}+\right.$ $\mathrm{HCO}_{3}$ ); therefore, carbonate dissolutions are the controlling process for both basins. Cation exchange is a significant groundwater composition controlling process for Area-1 and Area-2.

Factor analysis for Area-1 found that $69 \%$ of the variation in groundwater quality among the studied wells corresponded to the measured parameters. Area-2 factor analysis found that $73 \%$ of the variation in ground water quality among the studied wells corresponded to the measured parameters, $\mathrm{Na}^{+}, \mathrm{Cl}^{-}$, $\mathrm{Ca}^{2+}, \mathrm{K}^{+}, \mathrm{Mg}^{2+}$, and $\mathrm{NO}_{3}^{-}$. The wells for Area-1 and Area-2 were classified into three water quality groups using cluster analysis as discussed before.

\section{References}

[1] Abu-Jaber, N.S., Kimberly, M. and Cavaroc, V. (1989) Mesozoic-Palaeogene Basin 
Development within the Eastern Mediterranean Borderland. Journal of Petroleum Geology, 12, 419-436. https://doi.org/10.1111/j.1747-5457.1989.tb00241.x

[2] Diabat, A. and Masri, A. (2005) Orientation of the Principal Stresses along ZerqaMa'in Fault. Mu' tah Lil-Buhuth Wad-Dirasat, 20, 57-71.

[3] Bender, F.(1974) Geology of the Arabian Peninsula-Jordan. United States Geological Survey Professional Paper No. 560-1, Washington, 36 p.

[4] Abed, A. (1982) On the Hydrocarbons of Some Jordanian Oil Shales. Dirasat, 9, 63-79.

[5] Hufnagel, H. (1985) Oil Shale in Jordan. Natural Resources and Development, 22, 46-62.

[6] Beydoun, Z.R., Futyan, A.I. and Jawzi, A.H. (1994) Jordan Revisited: Hydrocarbon Habitat and Potential. Journal of Petroleum Geology, 17, 177-194.

https://doi.org/10.1111/j.1747-5457.1994.tb00125.x

[7] Abed, A.M., Aroura, K.H. and Boreham, C.J. (2005) Source Rock Potential of the Phosphorite Bituminous Chalk-Marl Sequence in Jordan. Marine and Petroleum Geology, 22, 413-425. https://doi.org/10.1016/j.marpetgeo.2004.12.004

[8] Ghassan, A. (1999) The Geology of Wadi Rajil Map Sheet No. 3653-IV, NRA, Geology Directorate, Bulletin 45, Amman-Jordan.

[9] Masri, M. (1963) Report on the Geology of the Amman-Zarqa Area. Unpublished Report, Central Water Authority, Amman.

[10] Wolfart, R. (1959) Geology and Hydrogeology of the Irbid District (Hashemite Kingdom of Jordan).

[11] Parker, D.H. (1970) The Hydrogeology of the Mesozoic-Cenozoic Aquifers of the Western High Land and Plateau of East Jordan. AG2: SF/JOR, Technical Report No. 2, UNDP/FAO, Rome, 424 p.

[12] Hunting Technical Services Ltd. and MacDonald, M. and Partner (1965) East Bank Water Resources. Vol. 6, Central Water Authority, Amman.

[13] Ibrahim, K. (1996) The Geology of Wadi Gharandal Area. Map Sheet No. 3050-II, NRA, Geo. Dir., Geol. Map. Div., Amman.

[14] APHA (1995) Standard Method for the Examination of Water and Wastewater. 19th Edition, American Public Health Association, Washington DC.

[15] Kehew, A.E. (2001) Applied Chemical Hydrogeology. Prentice Hall, Upper Saddle River.

[16] Fetter, C.W. (1994) Applied Hydrogeology. 3rd Edition, Macmillan College Publishing Company, New York.

[17] World Health organization (2011) Guidelines for Drinking-Water Quality. 4th Edition, WHO Library Cataloguing-in-Publication Data.

[18] Dojlido, J. and Gerald, A.B. (1993) Chemistry of Water and Water Pollution. E. Horwood, New York.

[19] Hem, J.D. (1985) Study and Interpretation of Chemical Characteristics of Natural Water. 3rd Edition, Geological Survey Water-Supply Paper 2254, United States Government Printing Office, Washington DC.

[20] Davis and Dewiest (1966) Hydrogeology. John Wiley and Sons, Inc., Hoboken, 463 p.

[21] Bireir, F.A. (2002) The Geochemical Evolution of the Groundwater in Gash Alluvial Using Isotope Hydrochemistry in Semi-Arid Area. NE Sudan. PhD Thesis, Institute of Sciences, Tsukuba.

[22] Sawyer, C.N. and McCarty, P.L. (1985) Chemistry for Environmental Engineering. 
3rd Edition, International Student Edition.

[23] Appelo, C.A. and Postma, D. (2005) Groundwater, Geochemistry and Pollution. Balkema, Leiden. https://doi.org/10.1201/9781439833544

[24] Hounslow, W.A. (1995) Water Quality Data, Analysis and Interpretation. Lewis Publishers, New York.

[25] Langguth, H.R. (1966) Die Grundwasserverhaltnisse Bereich des Velberter Sattels Rheinisches Schiefergeberge, Der Minister fuer Ernaehrung, Landwirtschaft und Foersten. NRW, Dusseldorf, $127 \mathrm{p}$.

[26] Lloyd, J.W. and Heathcoat, J.A. (1985) Natural Inorganic Chemistry in Relation to Groundwater. Clarendon Press, Oxford.

[27] Helena, B., Pardo, R., Vega, M., Barrado, E., Fernandez, J.M. and Fernandez, L. (2000) Temporal Evolution of Groundwater Composition in an Alluvial Aquifer (Pisuerga River, Spain) by Principal Component Analysis. Water Research, 34, 807 816. https://doi.org/10.1016/S0043-1354(99)00225-0

[28] American Public Health Association (APHA), American Water Works Association (AWWA) and Water Environments Federation (WEF) (2013) Standard Method for the Examination of Water and Wastewater. 22nd Edition.

[29] Davis, J.G. (1973) Statistics and Data Analysis in Geology. John Wiley and Sons, Inc., New York, 473-524.

[30] Al-Rawi, S.M. and Shihab, M.S. (2005) Application of Factor Analysis as a Tool for Water Quality Management of Tigris River within Mosul City. Rafidain Journal of Science, 16, 56-64.

Submit or recommend next manuscript to SCIRP and we will provide best service for you:

Accepting pre-submission inquiries through Email, Facebook, LinkedIn, Twitter, etc. A wide selection of journals (inclusive of 9 subjects, more than 200 journals)

Providing 24-hour high-quality service

User-friendly online submission system

Fair and swift peer-review system

Efficient typesetting and proofreading procedure

Display of the result of downloads and visits, as well as the number of cited articles

Maximum dissemination of your research work

Submit your manuscript at: http://papersubmission.scirp.org/

Or contact jwarp@scirp.org 